profitability and liquidity found that there is negative relation between the business's liquidity and its profitability Abuzarand Eljelly (2004).Working capital management is important due to its direct relation with the firm's profitability and liquidity Singh and Pandey (2008). According to Walt (2009) Profitability can be turned into liquid asset that's why it is more important but this never means that company is profitable if its liquidity is high. Liquidity is more important than profitability because it has impact on the survival of the company Don (2009).According to Dong (2010) Working capital management affects the liquidity and profitability of any firm. Fixed and current assets are important for the successful running of any business and these both have direct impact on liquidity and profitability Saswata Chatterjee (2010) .According to Deloof (2003) and Wang (2002) the working capital management increases profitability by reducing average collection period and inventories. According to Afza and Nazir (2007) there is a negative relation between the profitability and business's working capital investment and the financing policies. Mahmood and Qayyum, (2010) argue that the liquidity and profitability are important to achieve two main objectives profitability is related to the wealth maximization goal of the shareholders and liquidity is important for the continuity of business. Correlation and regression study of Eljelly (2004) founded that Current ratio is more important to measure profitability and cash conversion cycle is more important to measure liquidity. According to Shim and Siegel (2000) Liquidity is business capacity to pay short- term debts means their maturity is less than one year. Economic success achieved by any business by investing capital in it is said to be its profitability and it is determined by the net profit margin (Pimentel et al, 2005). High financial cost and business's inability to pay its obligations are the results of low liquidity (Maness \& Zietlow 2005).Liquidity tells about the firm's degree of independence against the creditors and it also tells about the difficulties and crises face by the company Matarazzo (2003). Financial strength of a business is measure of it liquidity Chandra (2001). Profitability will be lower the more funds are invested in current assets Assaf Neto (2003). The relation of profitability to liquidity is inverse according to Marques and Braga (1995) and Renato Schwambach Vieira (2010).Liquidity is commonly measured by current ratio and profitability is commonly measured by ROI Vishnani and Shah (2007).

\section{OBJECTIVE OF THE STUDY}

1. Evaluate the liquidity postion of seletced pharma companies in the Indian market using financial ratios

2. Evaluate the profitability ostion of seletced pharma companies in the Indian market using financial ratios

3. Analysing the relationship between liquidity and profitability amongst the selected pharma copanies in India.

\section{RESEARCH METHODOLOGY}

The study covers 5 pharma companies that are listed in the NIFTY pharma Index for the duration of 5 years. The study mainly uses secondary data for the analysis. The study compares the relationship between profitability and liquidity, where profitability is expressed using Gross profit ratio, Net profit ratio \& Operating profit ratio, whereas Liquidity is expressed using Current ratio and quick ratio. The data for computing the ratios were obtained from the Annual reports of the respective companies. The following hypothesis was set for the study:

H0: There is a significant relationship between profitability and Liquidity.

H1: There is no significant relationship between profitability and Liquidity.

\section{ANALYSIS OF THE STUDY}

Analysing both table 1 and table we can see that the trend shows in terms of the ratios that is current ratio quick ratio net profit ratio gross profit ratio operating profit ratio all seem to have the fluctuating trend year on year. In terms of current ratio where the standard is 2 is to 1 most of the companies were able to maintain standard except for Sun Pharma. It was seen that Aurobindo Pharma have a huge amount into current assets which raised the level of current ratio maintain by them. In terms of quick ratio all companies maintained slightly above the standard of 1 is to 1 except for Sun Pharma. In terms of gross profit net profit and operating profit ratio the company is generally did well. The only exception to this Sun Pharma which performed miserably from 2014 onwards. 
International Journal of Trend in Scientific Research and Development (IJTSRD) ISSN: 2456-6470

\begin{tabular}{|c|c|c|c|c|c|c|c|c|c|c|}
\hline YEARS & \multicolumn{2}{|l|}{2012} & \multicolumn{2}{|c|}{2013} & \multicolumn{2}{|c|}{2014} & \multicolumn{2}{|l|}{2015} & \multicolumn{2}{|l|}{2016} \\
\hline Ratios & $\mathbf{C R}$ & QR & $\mathbf{C R}$ & QR & CR & QR & $\mathbf{C R}$ & QR & $\mathbf{C R}$ & QR \\
\hline CIPLA & 3.70 & 1.38 & 3.61 & 1.35 & 3.14 & 1.15 & 2.82 & 0.98 & 3.25 & 1.07 \\
\hline DRREDDY & 2.31 & 1.37 & 3.24 & 1.96 & 3.34 & 2.22 & 3.33 & 2.25 & 3.01 & 1.78 \\
\hline AUROBINDOPHARMA & 4.31 & 2.07 & 3.54 & 1.80 & 3.57 & 2.09 & 4.71 & 2.76 & 5.14 & 3.11 \\
\hline SUNPHARMA & 3.20 & 2.09 & 2.64 & 1.05 & 2.65 & 0.61 & 0.99 & 0.41 & 1.07 & 0.44 \\
\hline LUPIN & 2.85 & 1.42 & 3.07 & 1.56 & 3.63 & 2.24 & 2.94 & 1.58 & 4.60 & 2.90 \\
\hline
\end{tabular}

Table 1: Table showing CR(current ratio) \& QR(quick ratio)

\begin{tabular}{|c|c|c|c|c|c|c|c|c|c|c|c|c|c|c|c|}
\hline YEARS & \multicolumn{3}{|c|}{2012} & \multicolumn{3}{|c|}{2013} & \multicolumn{3}{|c|}{2014} & \multicolumn{3}{|c|}{2015} & \multicolumn{3}{|c|}{2016} \\
\hline Ratios & GP & $\mathbf{O P}$ & $\mathbf{N P}$ & GP & $\mathbf{O P}$ & $\mathbf{N P}$ & GP & OP & $\mathbf{N P}$ & GP & OP & NP & GP & OP & NP \\
\hline CIPLA & $\begin{array}{l}0.2 \\
4\end{array}$ & $\begin{array}{l}0.2 \\
5\end{array}$ & $\begin{array}{l}0.1 \\
6\end{array}$ & $\begin{array}{l}0.2 \\
8\end{array}$ & $\begin{array}{l}0.2 \\
9\end{array}$ & $\begin{array}{l}0.1 \\
8\end{array}$ & $\begin{array}{l}0.2 \\
3\end{array}$ & $\begin{array}{l}0.2 \\
4\end{array}$ & $\begin{array}{l}0.1 \\
5\end{array}$ & $\begin{array}{l}0.1 \\
9\end{array}$ & $\begin{array}{l}0.2 \\
1\end{array}$ & $\begin{array}{l}0.1 \\
2\end{array}$ & $\begin{array}{l}0.1 \\
8\end{array}$ & $\begin{array}{l}0.1 \\
9\end{array}$ & $\begin{array}{l}0.1 \\
2\end{array}$ \\
\hline DRREDDY & $\begin{array}{l}0.2 \\
3 \\
\end{array}$ & $\begin{array}{l}0.2 \\
4\end{array}$ & $\begin{array}{l}0.1 \\
4\end{array}$ & $\begin{array}{l}0.2 \\
5\end{array}$ & $\begin{array}{l}0.2 \\
5\end{array}$ & $\begin{array}{l}0.1 \\
5\end{array}$ & $\begin{array}{l}0.2 \\
9\end{array}$ & $\begin{array}{l}0.3 \\
0\end{array}$ & $\begin{array}{l}0.2 \\
0\end{array}$ & $\begin{array}{l}0.2 \\
5\end{array}$ & $\begin{array}{l}0.2 \\
6 \\
\end{array}$ & $\begin{array}{l}0.1 \\
7\end{array}$ & $\begin{array}{l}0.2 \\
3\end{array}$ & $\begin{array}{l}0.2 \\
3\end{array}$ & $\begin{array}{l}0.1 \\
3\end{array}$ \\
\hline $\begin{array}{l}\text { AUROBINDOPHAR } \\
\text { MA }\end{array}$ & $\begin{array}{l}0.0 \\
0\end{array}$ & $\begin{array}{l}0.0 \\
6\end{array}$ & $\begin{array}{l}- \\
0.0 \\
1\end{array}$ & $\begin{array}{l}0.1 \\
4\end{array}$ & $\begin{array}{l}0.1 \\
8\end{array}$ & $\begin{array}{l}0.0 \\
9\end{array}$ & $\begin{array}{l}0.2 \\
4\end{array}$ & $\begin{array}{l}0.2 \\
8\end{array}$ & $\begin{array}{l}0.1 \\
6\end{array}$ & $\begin{array}{l}0.2 \\
7\end{array}$ & $\begin{array}{l}0.2 \\
9\end{array}$ & $\begin{array}{l}0.1 \\
9\end{array}$ & $\begin{array}{l}0.2 \\
6\end{array}$ & $\begin{array}{l}0.2 \\
9\end{array}$ & $\begin{array}{l}0.1 \\
8\end{array}$ \\
\hline SUNPHARMA & $\begin{array}{l}0.4 \\
5\end{array}$ & $\begin{array}{l}0.4 \\
5\end{array}$ & $\begin{array}{l}0.4 \\
2\end{array}$ & $\begin{array}{l}0.3 \\
1\end{array}$ & $\begin{array}{l}0.3 \\
1\end{array}$ & $\begin{array}{l}0.2 \\
1\end{array}$ & $\begin{array}{l}- \\
0.9 \\
5\end{array}$ & $\begin{array}{l}- \\
0.9 \\
5\end{array}$ & $\begin{array}{l}- \\
1.0 \\
0\end{array}$ & $\begin{array}{l}- \\
0.1 \\
1\end{array}$ & $\begin{array}{l}- \\
0.0 \\
4\end{array}$ & $\begin{array}{l}- \\
0.1 \\
8\end{array}$ & $\begin{array}{l}- \\
0.0 \\
8\end{array}$ & $\begin{array}{l}- \\
0.0 \\
1\end{array}$ & $\begin{array}{l}- \\
0.1 \\
4\end{array}$ \\
\hline LUPIN & $\begin{array}{l}0.2 \\
1 \\
\end{array}$ & $\begin{array}{l}0.2 \\
2 \\
\end{array}$ & $\begin{array}{l}0.1 \\
5\end{array}$ & $\begin{array}{l}0.2 \\
6 \\
\end{array}$ & $\begin{array}{l}0.2 \\
7 \\
\end{array}$ & $\begin{array}{l}0.1 \\
8 \\
\end{array}$ & $\begin{array}{l}0.3 \\
7 \\
\end{array}$ & $\begin{array}{l}0.3 \\
7 \\
\end{array}$ & $\begin{array}{l}0.2 \\
6 \\
\end{array}$ & $\begin{array}{l}0.3 \\
6 \\
\end{array}$ & $\begin{array}{l}0.3 \\
6 \\
\end{array}$ & $\begin{array}{l}0.2 \\
5 \\
\end{array}$ & $\begin{array}{l}0.3 \\
7\end{array}$ & $\begin{array}{l}0.3 \\
7 \\
\end{array}$ & $\begin{array}{l}0.2 \\
5 \\
\end{array}$ \\
\hline
\end{tabular}

Table 2- Table showing GP(gross profit), NP(Net profit) \& OP(operating profit)

Analysis of the correlation between profitability variables and liquidity variables have been shown in table 34 and 5. On analyzing table 3 which shows the correlation between gross profit ratio and liquidity ratios we can see that there is significantly high degree positive correlation between gross profit ratio and liquidity ratios. The only exceptions in the sample considered was that of Aurobindo Pharma and Sun Pharma in the correlation of current ratio and gross profit ratio, which was still positive but relatively low compared to other samples.

\begin{tabular}{|l|l|l|}
\hline COMIPANIES & $\begin{array}{l}\text { CORREL } \\
\text { CR/GPR }\end{array}$ & $\begin{array}{l}\text { CORREL } \\
\text { QR/GPR }\end{array}$ \\
\hline CIPLA & 0.72 & 0.86 \\
\hline DRREDDY & 0.61 & 0.74 \\
\hline AUROBINDOPHARMA & 0.30 & 0.63 \\
\hline SUNPHARMA & 0.16 & 0.62 \\
\hline LUPIN & 0.59 & 0.66 \\
\hline
\end{tabular}

Table 3- Table showing correlation between Gross profit ratio and Liquidity ratios

Analysing table 4 which shows the correlation between operating profit ratio and liquidity ratios we can see that same relatively high degree of positive correlation exist between the variables. Here also the exceptions are Aurobindo Pharma and Sun Pharma which showed relatively low degree a positive correlation. 
International Journal of Trend in Scientific Research and Development (IJTSRD) ISSN: 2456-6470

\begin{tabular}{|l|l|l|}
\hline COMIPANIES & $\begin{array}{l}\text { CORREL } \\
\text { CR/OPR }\end{array}$ & $\begin{array}{l}\text { CORREL } \\
\text { QR/OPR }\end{array}$ \\
\hline CIPLA & 0.67 & 0.83 \\
\hline DRREDDY & 0.56 & 0.69 \\
\hline AUROBINDOPHARMA & 0.24 & 0.60 \\
\hline SUNPHARMA & 0.09 & 0.58 \\
\hline LUPIN & 0.59 & 0.67 \\
\hline
\end{tabular}

Table 4- Table showing correlation between operating profit ratio and Liquidity ratios

Analysing table 5 which shows correlation between net profit and the liquidity ratios we can see that the same relationship as seen in table 3 and table 4 exist in this table as well. Again while most of the sample depict high degree of positive correlation the exceptions was Aurobindo Pharma and Sun Pharma which showed low degree a positive correlation.

\begin{tabular}{|l|l|l|}
\hline COMIPANIES & CORREL CR/NPR & CORREL QR/NPR \\
\hline CIPLA & 0.82 & 0.92 \\
\hline DRREDDY & 0.67 & 0.80 \\
\hline AUROBINDOPHARMA & 0.27 & 0.62 \\
\hline SUNPHARMA & 0.18 & 0.65 \\
\hline LUPIN & 0.60 & 0.68 \\
\hline
\end{tabular}

Table 5- Table showing correlation between Net profit ratio and Liquidity ratios

\section{CONCLUSION}

From the above analysis you can come to a conclusion that there is a high degree of positive correlation between profitability and liquidity. This goes against the traditional theory that profitability and liquidity have a inverse relationship going to the Limited nature of financial resources. Hence the Null Hypothesis has been proved.

\section{REFERENCES}

1. Abuzar M.A. Eljelly, (2004) "Liquidity profitability tradeoff: An empirical investigation in an emerging market", International Journal of Commerce and Management, 14(2), pp.48 - 61 .

2. Afza, T. \& M. S. Nazir, (2007). Working Capital Management Policies of Firms: Empirical Evidence from Pakistan. Conference Proceedings of 9th South 1. 2. Asian Management Forum (SAMF), North South University, Dhaka, Bangladesh.
3. Assaf Neto, A. (2003). Finanças Corporativas e Valor. S^o Paulo: Atlas. Deloof, M. (2003). Does Working Capital Management Affects profitability of Belgian Firms? Journal of Business Finance \& Accounting. 30(3).

4. Dong H. P. (2010), "The Relationship between Working Capital Management and Profitability". International Research Journal of Finance and Economic. Issue-49.

5. Ibenta N.S (2005). Investment Analysis and Financial Management Strategy, (Enugu: Institute for Development Studies) pp.346 - 358.

6. Mahmood \& Qayyum. A. (2010). Working Capital Management and Corporate Performance of Manufacturing Sector in Pakistan, International Research Journal of Finance and Economics, 47.

7. Maness, T. S. \& Zietlow, J.T. (2005). Short-term Financial Management., Ohio: South Western/ Thomson Learning.

8. Marques, J. A. C., \& Braga, R. (1995) AnJlise dinâmica do capital de giro: o Modelo Fleuriet. RAE - Revista de Administraç̧o de Empresas. 35 (3) 49-63. 
International Journal of Trend in Scientific Research and Development (IJTSRD) ISSN: 2456-6470

9. Matarazzo, D. C. (2003). AnJlise Financeira de Balanços. S^o Paulo: Atlas, 2003.

10. Osiegu .P.I and Nwakanma C. (2008). Financial Management, (Port Harcourt: Harey publications company) PP.156 and 171. Oxford Dictionary Of Accounting, Third Edition

11. Pandey M. I (2005). Financial Management, Ninth Edition, (New Delhi: Vikas, Publishing House put Limited) p.35 and 368. 